\title{
LCIA of pesticides: When active substances are spread into the environment 27 March 2003, ETH Zurich, Switzerland
}

\author{
Journal Article \\ Author(s): \\ Geisler, Georg \\ Publication date: \\ 2003
}

Permanent link:

https://doi.org/10.3929/ethz-b-000423087

Rights / license:

In Copyright - Non-Commercial Use Permitted

Originally published in:

The International Journal of Life Cycle Assessment 8(1), https://doi.org/10.1007/BF02978751 


\section{Awards: Business Innovation and Environment}

\section{Entrepreneurship, Innovation, and Life Cycle Management}

Aqua + Tech Specialties S.A. Wins 2002 Business Innovation and Environment Awards of the Wall Street Journal

\section{Gerald Rebitzer}

Sustainable Development/Life Cycle Management, DC-IGC-LPBM, Swiss Federal Institute of Technology, CH-1015 Lausanne, Switzerland (Gerald.Rebitzer@epfl.ch)

AQUA+TECH Specialties S.A. is a company situated in Geneva, Switzerland, which develops, produces, and sells materials for diverse applications in water treatment. More specifically, the core business of this SME encompasses different polymeric flocculants for separating solid-based impurities from aqueous suspensions such as sludges from municipal wastewater treatment, chemical processes, and mining. In addition, life cycle management (LCM) services in the form of consulting as well as implementation for their own and similar operations are part of the product portfolio. For their achievements in developing and marketing chemicals and services for environmental and other applications, AQUA+TECH, represented by its CEO DAVID HUNKELER, who is a very active member of the editorial board of Int J LCA and the new LCM section thereof, received the Wall Street Journal 2002 Bronze Price for Business Innovation and the Gold Prize for Best Environmental Firm (Wall Street Journal, 29.11.2002).

For several years, David Hunkeler, who co-founded the firm 1997 together with José Hernández Barajas, has been one of the strongest advocators for linking environmental life cycle thinking and LCM to business management. He recognized very early that systems thinking in environmental management offers opportunities for business development and growth and is possibly the only effective option for industrial advancements in sustainable development. The recognition of his efforts in putting life cycle management into practice by the Wall Street Journal demonstrates that his approaches, ideas, and concepts (see e.g., Hunkeler and Biswas 2000, Hunkeler 2003, Hunkeler et al. 2003) are not only academically relevant, but are proven success stories in the business world. AQUA+TECH can truly be viewed as a role model for the successful implementation of life cycle thinking and environmental management. These achievements challenge the widely existing, however speculative, belief that environmental leadership in LCM is a luxury only affordable for large multinational corporations.

For instance, AQUA+TECH's strategy of Selective Multinationality (see Hunkeler 2003) - based on the idea that SMEs can be international firms provided they seek niche markets where they can impose themselves as the first (or dominant) seller, or they look for strategic joint ventures which combine product and service synergies with existing client bases - shows how environmental considerations can be a key advantage of innovative companies of all sizes. In summary, AQUA+TECH's development and success can be seen as a proven business case for sustainable development, which should inspire other firms to exploit the untapped potentials of LCM. More information on the activities and products of AQUA+TECH can be found at www.aquaplustech.ch.

\section{References}

The Wall Street Journal (US and Europe edition), Friday/Saturday/Sunday Issue, 29.11.2002

Hunkeler D (2003): Selective Multinationality: How Environmental Management Helps High-Tech SMES Identify High-Growth, LowRisk Markets. Int J LCA 8 (1) 51-54

Hunkeler D, Biswas G (2000): Return on Environment - An Objective Indicator to Validate Life Cycle Assessments? Int J LCA 5 (6) 358362

Hunkeler D, Saur K, Stranddorf H, Rebitzer G, Schmidt W.-P, Jensen AA, Christiansen K (2003): Life Cycle Management. SETAC, in review (to be published in 2003)

\section{LCA-Discussion Forum 19}

\section{LCIA of Pesticides: When Active Substances are Spread into the Environment}

\section{March 2003, ETH Zürich, Switzerland, 9:30 to 17:00}

The 19th Discussion Forum on LCA will give an overview on current practice and trends in the LCIA (Life Cycle Impact Assessment) of pesticides and provide an outlook for further method improvement. Methods used in LCIA and Risk Assessment will be analysed and compared. The aim is to gain insight and encourage discussions on the relevance of different exposure pathways and impacts on humans and the environment, and their possible modelling in the LCIA of pesticides. The presentations and discussions are of interest to LCA researchers and practitioners.
Main speakers: Prof. Michael Hauschild (TU Delft), Prof. Olivier Joluet (EPFL), Dr. AndreAs Huber (Syngenta Crop Protection AG), and Dr. MARKus MülleR (Swiss Agricultural Research, SAR).

There is still some time available for short presentations (15 min. each). If you are interested in presenting your work on the LCIA or Risk Assessment of pesticides, or on case studies where pesticides play an important role, please contact geisler@tech.chem. ethz.ch. We hope that the Forum will be of interest to you and look forward to meeting you in Zürich.

Prof. Konrad Hungerbühler, Stefanie Hellweg, Georg Geisler 